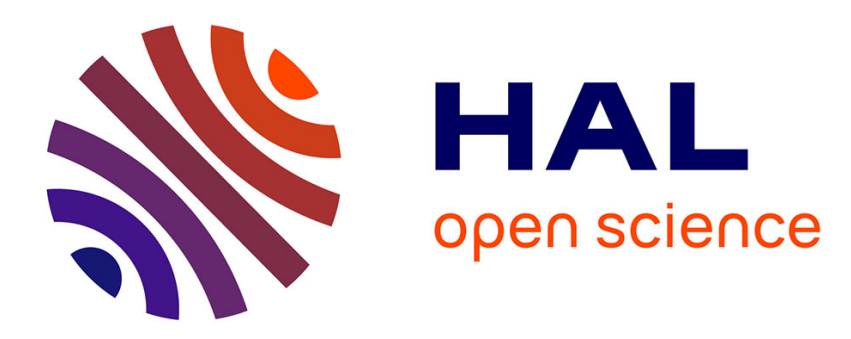

\title{
Underground and Underwater: Oil Security in France and Britain during the Cold War
}

Roberto Cantoni, Leucha Veneer

\section{To cite this version:}

Roberto Cantoni, Leucha Veneer. Underground and Underwater: Oil Security in France and Britain during the Cold War. The Surveillance Imperative. Geosciences during the Cold War and Beyond, , 2014, 978-1-137-43874-4. hal-01264562

\section{HAL Id: hal-01264562 \\ https://hal.science/hal-01264562}

Submitted on 1 Feb 2016

HAL is a multi-disciplinary open access archive for the deposit and dissemination of scientific research documents, whether they are published or not. The documents may come from teaching and research institutions in France or abroad, or from public or private research centers.
L'archive ouverte pluridisciplinaire HAL, est destinée au dépôt et à la diffusion de documents scientifiques de niveau recherche, publiés ou non, émanant des établissements d'enseignement et de recherche français ou étrangers, des laboratoires publics ou privés.

$$
\text { Copyright }
$$




\section{Chapter 2. Underground and underwater: gatekeeping oil exploration during the Cold}

War

Roberto Cantoni and Leucha Veneer

Abstract: In the first half of the Cold War several administrations in Western Europe sought to increase the amount of oil and gas that could be made available to their countries. These arrangements aimed to boost their national economies but they were also vital to energy security and molded the management of new discoveries and supplies of hydrocarbons at home and abroad. This paper focuses in particular on the plans outlined by the governments of two former imperial powers, France and Britain; their relationships with the superpowers; and those with neighboring partners and rivals. It shows how these administrations used different strategies of surveillance and diplomacy to gain and retain control of, and access to, strategically vital oil-rich areas, especially those in Algeria and in the North Sea. We conclude that geological exploration, and in particular oil prospecting, became another tool for nations long accustomed to intelligence gathering and surveying in the imperial context, to cater for their national energy security.

In the years following World War Two, global demand for oil increased continually, and Western European governments pursued various political and diplomatic strategies to obtain hydrocarbons as further reserves were revealed across the world. The tensions of the Cold War increased national concerns over energy security yet further, and in this essay we shall discuss some aspects of the particular strategies employed by two leading Western European administrations, to gain at least some control over the sources of their supply. These strategies 
included maneuvers such as stockpiling, encouraging diversification of supply, and, when the opportunity arose, controlling access to resources on home soil and abroad. This control required the mobilization of state and commercial geological surveying to obtain "geostrategic intelligence", that is to say gathering information on what oil and gas reserves could be found underground; finding out what others (whether enemies or allies, coproducers or business rivals) already knew about these reserves; and what acquisition strategies they had put in place. Surveillance in terms of both geophysical exploration and intelligence gathering was therefore an essential element of oil security; an element often neglected in the existing literature on the history of oil exploration. ${ }^{1}$ Oil surveillance operations also produced conflicts between diplomats, firm managers, government officials and geoscientists of different countries. As Robert Jervis more generally shows, the bolstering of energy security through surveillance activities by one administration made its neighbors feel less reassured about their own security. ${ }^{2}$ 
The Cold War may have, broadly speaking, divided the world in two, but within that division was a somewhat fragmented system of alliances. Using archival material, this paper focuses in particular on the traditional imperial powers of France and Britain because the international postwar order had forced both states into positions of lesser powers than before, their commercial and diplomatic footprints becoming accordingly smaller. Therefore their oil security circumstances appear unique. ${ }^{3}$ Moreover, both nations, due to that imperial past, were accustomed to maintaining significant numbers of scientific and intelligence personnel abroad, especially in colonies and countries that had recently gained independence. Here we reveal that these energy security urgencies prompted French geo-scientific personnel to start exploring Algeria at the end of World War Two. In Britain at a slightly later date, following the embarrassment of the Abadan and Suez Crises, ${ }^{4}$ the discovery of gas in the North Sea started a rush for oil there as Britain sought self-sufficiency in fulfilling its energy needs.

\section{The Secret Struggle for Algerian Oil}

When World War Two ended the French government was not the only Western European administration concerned about how to source oil to fuel the nation. However, its officials were more alert to the plans of other countries asserting a presence in the world's oil-rich regions. Cold War divides notwithstanding, the plans of their allies worried French government officials more than the distant Russian bear, especially as British and US oil firms held a dominant position in the French metropolitan oil market. The French oil industry was the largest in Europe before the conflict, but after 1945 it had to completely rebuild. Furthermore, its main source of supply in the Middle East was lost; an element that forced the French to be more vigilant both in terms of finding new deposits and controlling what other countries were doing. ${ }^{5}$ 
France's largest oil company, the Compagnie française des pétroles (CFP), had maintained a presence in the Middle East, and owned shares in the Iraq Petroleum Company (IPC), a consortium that also included the Anglo-Dutch Royal Dutch Shell, the Anglo-Iranian Oil Company (controlled by the British Government), and five American companies. But at the end of the conflict British and US oil majors challenged the so-called Red Line Agreement that ensured equal IPC shares within the territories of the former Ottoman Empire (see figure 2.1). The dispute revealed to French government officials that the US administration had allowed American oil companies to challenge the status quo in the

[Figure 2.1 approximately here!]

extraction and distribution of oil supplies from the Middle East. The war had quite evidently established new balances of power in the region. Moreover, the US companies Standard Oil of New Jersey and Standard Oil of New York now wanted to take a larger share of Saudi oil; in order to do so, they had to rid themselves of the constraints of the Red Line. Anglo-Iranian and Shell were willing to appease the Americans and did nothing to stop the ArabianAmerican Oil Company (ARAMCO), which was not originally part of the IPC and held concessions in Saudi Arabia, from “crossing” the Red Line. So in the spring of 1946, Jersey Standard publicly declared that they considered the agreement to have lapsed, owing to France's wartime status as an enemy power during the period of the Vichy regime. ${ }^{6}$ During an autumn visit to Europe, representatives of the American oil majors further bolstered the US position by maintaining that the Sherman Antitrust Act forbade them to respect the restrictive provisions of the agreement, which would amount to cartelization. ${ }^{7}$

The secret deals between Americans and British convinced the French that they ought to reinforce their information-gathering activities on foreign oil agreements. At a CFP board meeting in December 1946, Director René de Montaigu confirmed press rumors that Jersey 
and New York Standards had acquired shares in ARAMCO, while President Victor de Metz informed the board of a new agreement between Anglo-Iranian and the two Standards. ${ }^{8}$ The deal reassured British and US governments about controlling oil provisions in the Middle East at the expense of French energy security. During the next twenty years the British government-controlled AIOC sold Jersey 160 million tons (Mt) of crude, and the two companies jointly built a pipeline linking the Persian Gulf to the Mediterranean. ${ }^{9}$ The British used it for their Kuwaiti crude, which they exploited on a fifty-fifty basis with Gulf (another US firm). Shell's neutrality was also acquired through a very favorable contract allowing the company free access to Kuwaiti oil: from May 1947, Gulf provided 30 percent of Shell's crude oil requirements in the Eastern Hemisphere. ${ }^{10}$

Naturally, the CFP managers understood that American and British governments had done nothing to prevent this situation (in fact they had encouraged it), but it was especially the extension of British and US oil interests in Northern Africa that the French could not stomach. With the Treaty of Paris of 1947, Libya ceased to be an Italian colony: two of its three regions, Cyrenaica and Tripolitania, passed under British military control while the third, Fezzan, was controlled by the French. According to journalist Pierre Fontaine, a "secret battle" now ensued between British and French administrations to draw the borders between Cyrenaica and the potentially oil-rich Fezzan region. An army of scientific experts was mobilized to find out how much oil could be sourced out from this region and what the British were after. Thanks to pioneering prospecting activities carried out by geologist Conrad Kilian in the 1920s and 1930s, French oil authorities were in fact fully aware of the region's potential. ${ }^{11}$ In 1942 Kilian had even been approached by ARAMCO and Shell consultants, who lured him into revealing them his Saharan secrets, but he had rejected their offers. $^{12}$ 
Kilian now considered it imperative that the CFP establish a partnership with US oil concerns in prospecting work. In 1947 the French geologist met Jean Bédier, director of the powerful Banque de Paris et des Pays-Bas and showed him his findings. With the help of the former director of the Office National des combustibles liquides, Bédier thus submitted a project calling for the establishment of a French-American consortium for the exploration and exploitation of Fezzan. French officials now understood that establishing a consortium would mollify American diplomacy in the dispute with the British for the definition of Libya's internal borders and encouraged the deal. ${ }^{13}$ However at the last minute Kilian withdraw his support and the secrets of Fezzan's underground would remain hidden for some time.

Kilian had also urged the French government to prospect Algeria for hydrocarbons. His observations on the sediments of the Hoggar area, in the Sahara, suggested the existence of geological conditions apt to the presence of oil. In November 1948 his report was passed on to the French Académie des Sciences, sealed in a box, and stayed untouched until the geologist's death three years later. ${ }^{14}$ Kilian's hypotheses on the area turned out to be only partially accurate, but his work paved the way to the exploration of the Sahara desert, and instigated the CFP to prospect more. ${ }^{15}$ The dispute between British and French governments on Fezzan continued and, by the end of the 1940s, it was informed by other factors. The Soviets sought to support Arab nationalism in the region, partly in an effort to gain control of oil resources. US and British oil companies now stealthily mobilized their own scientific monitoring networks to search for new oilfields out of Soviet and French reach. To this effect the British even employed a geologist turned diplomat and military intelligence agent: Francis James Rennell Rodd. A specialist in the study of oil-bearing structures of the Fezzan region and a collaborator to the International Geological Map of Africa, Rodd exploited his knowledge of local territories and local elites in an attempt to gain control of its yet untapped oil deposits. ${ }^{16}$ 
Meanwhile, the information that the French had secretly acquired on the dealings of the Standards and ARAMCO in the Middle East was passed on to their government's legal departments with a view to launching proceedings in international courts. In 1946 de Metz urged that CFP's board take legal action at the British High Court of Justice against the American consortium's decision to terminate the Red Line Agreement. ${ }^{17}$ Two governmental commissars, the Fuel Director and President of the Bureau de recherches de pétrole (BRP), Pierre Guillaumat, and the President of the Bank of Algeria, Jacques Brunet, supported de Metz's proposition. It is important to note that during World War Two Guillaumat had worked together with the French intelligence in Tunisia and Algeria. Like Rodd, he had gathered information on foreign territories, their resources and secretly managed details on oil deposits. He would play a decisive role in reorganizing the oil prospecting sector using this knowledge. Having to face the Anglo-American dealings in the Middle East excluding France, Guillaumat retaliated by seeking to reduce the influence of British and American oil interests in the French metropole. He also instructed the French Ambassador in Washington to deliver a letter of formal protest against the US denunciation of the Red Line agreement. ${ }^{18}$

On the eve of the first court hearing on this agreement in London, a Shell representative, John Boyle, proposed a compromise to de Metz and de Montaigu. The IPC would supply CFP as its managers wished, and a new pipeline would be built from Kirkuk to the Mediterranean Sea. The counterproposal was accepted but de Metz only agreed to postpone legal proceedings. The following February the French filed the court petition again hoping now to force the Americans to re-open negotiations. ${ }^{19}$ In March the French Ambassador received a reply from George Marshall, the US Acting Secretary of State, so the legal challenge at least helped the French to force the Americans to compromise. By the end of May 1947 a settlement was reached. The CFP would withdraw its objections in exchange for an increase in its share of IPC production which would also be increased considerably its 
output to accommodate French oil demand. ${ }^{20}$ The Heads of Agreement were signed by all the major IPC partners a year later. ${ }^{21}$ British and Americans diplomats thus realized that the French government was prepared to make use of its experts, intelligence agents and lawyers in defense of oil security, or in order to force them to renegotiate existing agreements to increase French oil supplies in the wake of the Cold War. However, more security concerns soon arose in Paris and soon forced the French to reconsider their position in the Middle East consortium with a plan to invest more in North African resources.

\section{The scramble for oil in North Africa}

The new IPC deal appeared to be short-lived. The superpowers' influence in the Middle East increased quickly and dramatically, making diplomatic and oil relations more volatile. In 1946 the Soviet government had urged Iran to start up an oil exploration company, though the Iranians had later cancelled the deal and struck a military agreement with the US government. The Arab-Israeli war of 1948 led to the permanent closure of one of IPC's terminals. And both Iraqi and Iranian officials sought to obtain fifty-fifty contracts from the oil majors modeled on the one conceded by ARAMCO to Saudi Arabia. The new arrangements would make the two contracting parties equal partners, thus ending the exploiter-exploited relation characterizing previous contracts. The majors' refusal to agree on this request produced tensions and contributed to destabilize the area. The French government now decided to partly disengage from the Middle East. The decision was taken as a consequence of the reorganization of the oil administration at government level, and also because of the presence of Anglo-American interests within CFP; only 35 percent of its shares now belonged to the French state. 
The French Provisional Government led by Charles de Gaulle instigated the foundation of new public agencies responsible for exploring for oil in the French Union, as well as for the technical development of French know-how in oil exploration. It then urged these agencies to shift exploration from the Middle East to Africa, especially the Sahara desert and the Guinea Gulf. Threatening French oil security in the Middle East thus stimulated sweeping surveys in the French colonies. The creation of the oil exploration agency BRP, and the presence of former intelligence agent Guillaumat at its helm, marked the beginning of a new era in the history of French oil. BRP managers came from similar educational backgrounds as most of them had been trained at the Parisian military academy École Polytechnique and at the Corps des Mines, institutes that offered the most prestigious technical and engineering training in France. Soon a small group of experts, characterized by strong personal and political links took control of the French oil agencies. Many corpsards like Guillaumat - had entered the cadres of the French intelligence services during the war, and now engaged in bringing together intelligence and geological expertise. Guillaumat had also kept many informants in North Africa. André Rauscher, a Shell engineer in Tunisia and a fellow polytechnicien, had helped Guillaumat by spying on the Italian army's prospecting activities in Libya. Pierre Taranger of the Compagnie Générale de géophysique (CGG), and Léon Kaplan of Shell were also close to Guillaumat and directly involved in French oil exploration. $^{22}$

The French began to explore North Africa by using all techniques made available by CGG, especially through a grand gravimetry reconnaissance campaign in 1948, and through seismology from 1951. However, gravimetry was slow and its interpretation in the region proved hard; reflection seismology produced deceptive results, while photo-geology could not be applied outside the Saharan Atlas Mountains, where the mass of Mesozoic layers hindered surface geology. Because of these problems, the chief geologist of BRP's Algerian 
affiliate SN REPAL, Igor Ortynski, suggested that CGG apply seismic refraction; a method that had been out of fashion for decades, but which seemed to be more suitable to the geological characteristics of the Sahara desert. ${ }^{23}$ From 1952 CGG started a new campaign that produced more successful results. Besides eliminating the problem of multiple reflections, refraction seismology allowed penetrating younger geological layers and forming a picture of deeper layers. ${ }^{24}$

The accumulation of this knowledge on local underground resources helped the French to focus on specific areas to explore. Those in the French Union - as the area formerly included in the French Empire was called from 1946 - could now be used without previous negotiations or the establishment of new consortia. ${ }^{25}$ The Union was French territory and could therefore be treated as private ground. In the Algerian Sahara the BRP sponsored novel explorations through SN REPAL and with the collaboration of CFP. French experts thus gained a refined understanding of the geology of the Saharan region, which would soon prove of capital importance in the oil discoveries that took place between 1952 and 1954.

US and British oil concerns also developed an interest in Algerian oil and tried to get their shares of territory to explore. Guillaumat soon realized that Kilian's early findings and recently acquired geophysical knowledge should not be divulged, but this was not enough to grant safe and quick oil supplies from Algeria. The French needed to prospect more if they wanted energy autonomy within a few years. They were therefore faced with two main options: let the Anglo-American enterprises into the Sahara, and gain in efficiency, financial backing and technological knowledge; or continue their path independently at the risk of having to carry a colossal prospecting burden over many years. This second choice would be a dangerous scheme for a country heavily struggling with inflation. In June 1947, the French Director of General Affairs, Pierre Maisonneuve, organized a conference at the Under- 
Directorate of Algeria to discuss the prospecting plans of three foreign companies (Caltex, Gulf and AIOC) that had shown an interest in Algeria. ${ }^{26}$ Several ministries and oil company representatives (including that of SN REPAL) attended. Guillaumat argued that collaboration with foreign companies would be extremely profitable to the French economy, due to the shaky state of French finances. ${ }^{27}$ But his proposal to develop joint participations with these companies encountered resistance. The representative of the Algerian Government General, Henri Urbani, challenged Guillaumat's favorable attitude towards foreign companies, expressing his serious concern over a too permissive stance. ${ }^{28}$ What worried Urbani was especially lack of knowledge of what US crews were doing in Algeria and how much they knew about French operations:

First of all, every day we see Americans coming back and forth to Algeria. We don't know much about what they come to do, but what we do know is that they are interested in oil. [...] Once we will have given the Americans exploration permits, we will see them arriving in Algeria en masse and, from that moment on, what will their action be in the country ${ }^{29}$

Urbani's reservations were understandable: in June 1947 France was still very weak, both financially and politically, whereas the role of the US as a superpower had been made clear by the enunciation of the Truman Doctrine only three months earlier. There was little doubt that France would be forced to give in if the Americans decided to deploy all their influence in North Africa: even more so if they opted for a major prospecting effort; something that the French could not match. Urbani's point was thus that the French ought not to make concessions in order to have the upper hand in the region. Guillaumat, however, disagreed. He believed that few American companies could work outside the US with the same proficiency they had at home. Furthermore, he was not at all convinced that such frantic 
foreign activity had taken place from 1942 to 1945 in Algeria. As a former intelligence officer, and thanks to his relations with people such as Taranger, Guillaumat had access to restricted information that Urbani simply lacked. ${ }^{30}$ Lucien Bonneau, Plenipotentiary Minister and Director of Africa and Near East at the Foreign Ministry, also downplayed the extent of American influence in North Africa but showed wariness. If the Americans were determined to access North Africa, they would use their powerful transport or radio companies - and, undoubtedly, their secret services.

The notable difference of viewpoints between Urbani and Guillaumat was also discussed at SN REPAL's board meetings, where it was concluded that foreign assistance was needed only in the supply of materials and specialized drilling staff. SN REPAL took the lead in general operations, and only collaborated with foreign enterprises in associations where it held a majority of shares. ${ }^{31}$ Guillaumat succeeded in convincing his colleagues that collaboration in Algeria would not threaten French interests in the region. Was he really aware of what the British and Americans were really doing? While the French had been reconnoitering the Algerian underground, the Americans had been busy reconnoitering it from the sky.

\section{British and American attempts to enter Algeria}

The surveillance of potential oil-bearing areas in Algeria was a decisive element in establishing whether or not the oil majors would try to enter Algeria and whether the French could stop them. Guillaumat knew that during World War Two the US Air Force had taken aerial photographs in Algeria and that the photos contained details of geological structures that revealed the presence of oil deposits. After the war, the French government had agreed with US diplomats that photographic material ought not to be shared without prior French 
consent. On the other hand the French did not hold copies of these photographs either. ${ }^{32}$ In 1947 French officials authorized Jersey Standard experts to see the photographs and the following year an agreement signed at the French Embassy in Washington enabled the French Air Force's Chiefs of Staff to obtain copies of the photos. It is likely that SN REPAL obtained access to these copies as well. ${ }^{33}$

Caltex, Gulf, Anglo-Iranian and Shell had been attracted by the French exploratory activities in Algerian territories. Should oil be found, these companies were ready to wield the power they enjoyed as a result of the war in major exploratory campaigns. Yet, as they did not have access to the photos, they could not know enough about the real Algerian potential. So before setting foot in Algeria, they used their lawyers to sound out French reactions, and to determine from these reactions if the French had found oil deposits. In September 1947, one of Gulf's lawyers sent a letter to Yves Chataigneau, Governor General of Algeria, through the French Embassy in Washington. ${ }^{34}$ After that, Gulf received useful data on Algerian geology through the French Embassy and decided to begin large-scale works, provided the French government agreed. Gulf representatives now approached the officials of the Direction des carburants and BRP in Paris, and met Guillaumat and BRP's Delegate-General, Paul Moch. Gulf was ready to carry out prospecting works for over \$1 million, including surface geological and seismic works, and photogeology. ${ }^{35}$ We have seen that while Guillaumat saw favorably the collaboration with foreign interests, he wanted to retain absolute control of geological data. But Gulf demanded instead a series of guarantees, including the availability to Gulf of documentation kept by the Mine Service, SN REPAL, the Hydrography Service, as far as geology and oil exploration was concerned. Thus a conflict between different departments in the French government ensued and when Gulf applied for an exploration license, it was refused. ${ }^{36}$ 
The same strenuous opposition, however, did not characterize SN REPAL's board, which welcomed a collaborative project with an affiliate of the US oil firm Jersey. In 1947 Jersey had shown some interest for searching oil in Algeria and had obtained authorization to send a team of geologists and carry out a study on the oil potential of the Saharan region, provided an account of the team's activities was transmitted to SN REPAL. Jersey could even use the set of aerial photographs taken during the war by the US Air Force for its exploration. But the collaboration was short-lived. When the Americans realized (perhaps mistakenly) that the only area deemed to have serious commercial oil possibilities was one that would be assigned to SN REPAL, they pulled out. ${ }^{37}$

One reason for Guillaumat to encourage collaboration with foreign enterprises in Algeria was that he hoped to gain some influence in oil exploration projects in other areas of the world. In October 1951 Shell, through its affiliate Shell Française, informed the new Governor General of Algeria, Roger Léonard, of its intention to ask for a vast exploration permit. Guillaumat reckoned that room for Shell could be found in the Sahara if they accepted French participation in their exploration activities in Canada and Venezuela. Representatives of the Ministry of Finances and Economic Affairs stressed the difficulties of this solution but eventually the French administration allowed participation in Shell's works, together with a small contribution from BRP. ${ }^{38}$

That Guillaumat and his collaborators were willing to facilitate relations with foreign companies did not mean all the oil executives in French companies embraced his viewpoint, especially when yielding to those companies could jeopardize their primacy in the area. An episode regarding Shell and SN REPAL clearly shows this point. In February 1952 the President of SN REPAL, Roger Goetze, forwarded to Moch (the BRP Delegate General) two letters to urge him to consider the consequences of allocating foreign companies permits in 
areas bordering those requested by CFP-SN REPAL (see figure 2.2). Goetze stressed the existence of a clause contained in SN REPAL's permit allowing the company to prospect

[Figure 2.2 approximately here!]

outside its permit zone. The French had requested their permits in August 1950, earlier than Shell, but these had not yet been awarded. Furthermore, since geological knowledge about the area was less detailed at the time that SN REPAL had requested its permits, Shell could now ask licenses for more promising areas. Goetze pointed out that in the light of the new geological data about the Saharan basin it would be preferable to allow SN REPAL priority over Shell or other companies on unexplored areas. In order to prevent Shell from gaining uncontrolled access to the desired area, Goetze even proposed that SN REPAL take a financial stake in all companies engaged in the Sahara, especially in prospecting activities, so as not to miss any opportunity that might accrue. ${ }^{39}$ Eventually, although the requests jointly made by Shell and by the Régie autonome des pétroles (RAP, a French public oil agency) were approved, SN REPAL received the Governor's support to obtain a counselor seat with no financial stake, or a small stake (up to 5 per cent) in the companies to be formed by Shell and $\operatorname{RAP}^{40}$

The results of collaborative prospecting activities would eventually prove Guillaumat's strategy right, as they enabled the first major oil discoveries in Algeria. Up until the outbreak of the Algerian war in 1954, the Algerian Sahara remained firmly in French hands and provided France with the supply of oil it badly needed to cope with national demands. In 1953, the re-opening of Anglo-French negotiations on joint collaborative work led to the constitution of two companies, the Compagnie de recherche et d'exploitation de pétrole au Sahara (65 per cent RAP; 35 per cent Shell), and the Compagnie des pétroles d'Algérie (65 per cent Shell; 35 per cent RAP). ${ }^{41}$ In 1954 the first of these companies 
discovered the first gas field of commercial value in the area, and two years later also discovered the Edjeleh oilfield.

Thanks to the geophysical knowledge put compiled during the past ten years, the French administration could thus address its energy security needs. SN REPAL and BRP discovered in 1956 the two largest Algerian oil and gas fields, Hassi Messaoud and Hassi R'Mel, and kept control of them. Since the main American concern regarding the conflict was to keep the Soviets out of North Africa, the early Cold War tensions on oil supplies between American and British oil companies and the France administration relaxed somewhat. However, this situation was complicated by events in the late $1950 \mathrm{~s}$, principally the conflict for Algerian independence. While this paper does not discuss the impact of this conflict on French energy security in detail, it is worth mentioning that it partly upset the system of selective collaborations with foreign concerns that Guillaumat had put in place. In particular, both Italian and US firms now used the conflict as a lever to gain more influence in the exploitation of Algerian hydrocarbons. Meanwhile the French and the British joined forces in the Suez Canal crisis, thus overcoming their traditional enmity in oil affairs. This leads us to consider another case, that of the North Sea, where the gathering of knowledge on oil and gas fields was decisive in shaping relations between another former imperial power, Britain, and its neighboring countries.

\section{The Race for the North Sea}

The British case presents various points of contrast and comparison with the French, especially following the discovery of gas in the North Sea in 1959 (with the concomitant realization of the long-held expectation that there would also be oil). Up until then the British had not only - as we have seen - been active in North Africa and the Middle East, but had also been attempting to mobilize their allies to counter threats to oil security as much as 
possible. In particular, the oil disputes in the Middle East and North Africa between key Cold War allies highlighted to the British government the urgency of reaching agreements on oil security through supra-national organizations emanating from Cold War divisions. For instance, from the early 1950s Britain encouraged the defense alliance it belonged to, NATO, to take oil stockpiling seriously for both military and energy security purposes and mustered support for a Petroleum Planning Committee to look at the supply lines and storage of military and civilian oil across the alliance. The Committee was even made responsible for developing strategies to protect these supplies in the event of World War Three.

Another element producing anxiety in the British government was the diplomatic victory of Egyptian president Gamal Abdel Nasser in the Suez Crisis. This was bad for British oil security, but even worse for the French colonial interests, as, so the French claimed, Nasser was acting as a proxy between the Soviets and the Algerians, and was the main channel through which the North Africans received weapons supplies. The outcome of the Suez expedition strengthened the Algerian liberation movement, and made Nasser the champion of Arab nationalism. This outcome warned British policy-makers about existing threats to oil security and this continued to be a key issue in the administration of governmental affairs. Britain could now found itself isolated in its quest to secure more oil. Similarly to the French administrators at the BRP, their British colleagues at the Ministry of Power understood that the solution to the oil supply problem rested with the ability to know more about oil deposits underground. But in contrast with the French, the British found that the solution to their problems was much closer to home and required no intervention in colonies or former colonies.

So although underlying security concerns in Britain were similar to those of the French, the diplomatic and scientific pressures were different, and so were the strategies and 
fuel policies that the Ministry of Power adopted in response, the most important aspect of which, with regard to the North Sea, was to put together the essential information regarding gas fields so as to quickly establish control on its output through licensing. This was even more of an imperative as Britain had no state oil company, and was therefore reliant on commercial enterprise. The British government held a controlling stake in AIOC, but the company had been greatly changed by the Iranian government's decision to nationalize the Iranian oil industry in 1951, which had led to the Abadan Crisis. AIOC became the British Petroleum Company (BP) in $1954 .{ }^{42}$ Before the discovery of gas in the North Sea, the British Government encouraged companies such as BP, Shell and Esso to stockpile crude oil and diversify their sources of supply as much as possible. ${ }^{43}$ Nationalization never became part of the Ministry's strategy. The UK gas industry had been nationalized in 1948, but no state oil company was founded in Britain, even in the wake of the North Sea discoveries, for fear it would damage existing relations with the oil companies. ${ }^{44}$ Nor were these arguments ever simply about business methods and oil revenues: in the international Cold War context, there was the ever-looming possibility that Soviet military action might affect both civilian and military oil supplies from the Middle East, and the great risk inherent in British dependence on imported oil became starkly clear as domestic demand continued to rise.

In the early 1960 s, therefore, the British Government felt the potential threat to its supplies was serious, and quickly put into action a policy that not merely encouraged but actively forced rapid exploitation of North Sea oil through commercial and scientific avenues. Although oil and gas had been found just before WW2, from 1959 the location of the Slochteren gas field in the Groningen province produced a rush towards prospecting and finding more hydrocarbons. ${ }^{45}$ 
The UK Parliament soon passed a bill claiming sovereignty over all submarine resources on its continental shelf and in 1962 British Petroleum (BP) established the first offshore prospecting site in Weymouth Bay. However, BP experts knew that sites in British waters had limited prospect, whereas the North Sea basin which geologically resembled northern Netherlands had much more promise. ${ }^{46}$ Once the surveys (geological sampling, gravity and seismic) revealed that the richest field where placed in the Norwegian shelf, the British government sought to prevent other European countries from staking a claim on these fields by quickly reaching an agreement with Norway and licensing exploitation soon afterwards (see figure 2.3).

[Figure 2.3. approximately here]

The agreement, signed in 1964, was far more advantageous to the Norwegians than they had expected, but would enable oil companies supplying Britain to gain permits to pump gas out quickly and virtually unchallenged, offering "oil security" for the foreseeable future. The agreement with Norway over the division of all waters too far north for continental European countries to claim them was rapidly reached. ${ }^{47}$ So if French thirst for oil had led to attempted territorial expansion and control, then Britain now agreed to a slight reduction in territory in order to begin extraction at once. Exploration licenses were issued already in 1964, though a final agreement on the division of the North Sea was not concluded until 1972. By 1967, when the Minister of Power Richard Marsh reported to the House of Commons about fuel policy, 54 exploration wells had been drilled in the North Sea by at least 15 different companies. ${ }^{48}$

The deal with Norway, however, now compelled British authorities to constantly monitor the prospecting efforts of other countries and firms in the North Sea. The UK and Norway were, naturally, not the only countries hurrying to exploit resources on their 
continental shelves, and diplomatic negotiations over which companies from which countries had access to which nations' submarine resources became complicated and required a certain delicacy, For instance, although by the 1960s French and British administration had restored amicable relations on oil matters, the French still with the British in the North Sea and keeping tabs on neighbors' oil supply was still essential to acquisition strategies. But what really worried the Ministry of Power officials was Germany. In 1963 BP was excluded from a consortium that was to operate in the German North Sea and learnt that the French BRP was given licenses instead by West Germany. The following year, BP thus requested that the Ministry of Power arrange a diplomatic approach to the government of the Federal German Republic to enable BP's German subsidiary to gain access to the German North Sea. BP was excluded from a consortium that was to operate in this area because, the company was told, their interest had not been expressed soon enough. BP officials were reluctantly prepared to accept the decision. Yet they eventually learnt that the French BRP was admitted after BP was refused, and that BRP had expressed interest later BP had. Ministry of Power officials thus suggested to the Foreign Office that if BP was discriminated against, there might be reciprocity when it came to the issuing of licenses for British areas of the North Sea. In the end, BP became resigned to the situation when the Germans promised that the consortium would operate only in the German North Sea, and whole areas of German continental shelf in the Baltic remained open for other companies, BP included. ${ }^{49}$

The attitudes of both Ministry of Power officials and the companies themselves could change very quickly, though; especially when restricted information on other countries' intentions was made available. In 1966 another area of continental shelf, this time the Swedish Baltic, came under negotiation, and the Ministry of Power learnt from Foreign Office officials that believed the Swedish government was forming a consortium of Swedish companies to explore its own waters. Though the Swedes would have to buy in equipment 
and expertise, the British government - and $\mathrm{BP}$ - thought that the formation of the consortium indicated the probability the probability that foreign companies would not be permitted direct access. ${ }^{50}$ What worried them even more was that the Soviets might be luring the Swede somehow and be given access instead. Though the earlier case had not, in the end, resulted in either French or German companies being treated differently by the Minister of Power when he allocated licenses for the North Sea, the question was raised again for the Swedish case. Since British companies had not an urgent need to gain access to the Swedish continental shelf, British diplomats eventually agreed that there was no reason to openly challenge the decision. It seemed better to "adopt a liberal attitude ourselves and then take what credit we can for it rather than threaten reciprocal restrictions," as one Ministry official put it. ${ }^{51}$ Furthermore, there was another potential security issue with the Swedish Baltic Sea: if an open invitation to Western companies to prospect was demanded by Western governments, it would not be unreasonable to suppose that the USSR would begin to take an interest as well, and Russian pressure on Sweden was not something the West would welcome.

Not indifferently from the Algerian case, the accumulation and circulation of new geophysical knowledge on potential oil deposits played a key role in disputes on the North Sea licenses. The first license for British North Sea oil explorations had been issued by the Minister of Power in 1964/65 and expired in 1970. By 1967, therefore, some companies had been gathering more accurate geological data for two years, and all of them would continue to do so for another three. In contrast Ministry officials now realized that they would not be able to make sound evaluations on the reissuing of those licenses in the next round unless they possessed the same information. ${ }^{52}$ And since the urgency to explore the North Sea as quickly as possible remained, those licenses would have to be immediately re-issued. Although the British government did not have an equivalent of the BRP, like the French 
organization it compelled the companies that had licenses to share their raw data with, in this case the Ministry of Power, so that information could be made readily available to its officials and ensured them overall control over licensing. Now, however, the lack of scientific expertise amongst Ministry of Power to process the raw data created anxiety since the licensed oil firms would share the data but not their scientific interpretations. The Ministry of Power therefore turned to the newly established Institute of Geological Sciences (IGS, formerly the British Geological Survey) and its new director, Kingsley Charles Dunham. ${ }^{53}$

Although recently appointed, Dunham did not lack familiarity with the wider situation. He had a breadth of academic and commercial experience and was Professor of Geology at the University of Durham from 1950. He was familiar the mining sector internationally having been a consultant for several firms. Amongst these featured investigations for Iraq Petroleum in Oman and South Yemen and the reconnaissance of black minerals and deposits in South Africa. ${ }^{54}$ But one specific duty that made him very suitable for the tasks ahead was that he had served on the committee chaired by Sir Frederick Brundrett in 1963, which, along with the Trend report on the re-organization of government science, had recommended the formation of the IGS under the new research councils in 1965.

Unlike Guillaumat, Dunham was never involved in intelligence work. But serving in the Brundrett committee exposed him to the management style of one of Britain's pioneers of scientific intelligence, which Brundrett had developed during the war in the Royal Naval Scientific Service. Partly thanks to these activities, Brundrett rose through the ranks becoming head of the Atomic Energy Intelligence Committee and then science adviser to the Ministry of Defence. ${ }^{55}$ His connections with both scientific policy and the intelligence services were thus well established, and his influence had not waned with his retirement in 
1959; since he was still responsible for the Defence Research Policy Committee; the chief planning organization of defense research in Britain. ${ }^{56}$

Brundrett's policy review led to unify under the IGS geological work previously carried out separately by the Overseas Geological Survey and the geological survey unit of the Atomic Energy Division. ${ }^{57}$ It also more clearly directed IGS work towards oil security needs. Following a recommendation of fishery scientist Ray Beverton, assistant secretary of the newly established Natural Environment Research Council (NERC), Dunham agreed to the setting up of a up a Mineral Resources Consultative Committee (MRCC) under the aegis of the Department of Education and Science (DES). This enabled to share information (and concerns about data acquisition between various government agencies, including the DES, the Ministry of Power and the Ministry of Technology. ${ }^{58}$ The new committee now gave the IGS the mandate to looking at the geological and geophysical data available. ${ }^{59}$

As Director of the IGS, Dunham was therefore made aware of the overall implications of controlling information on natural resources -oil especially- and not merely the geological details. He was willing but cautious in the face of the Ministry of Power's demands: he did not have sufficient staff; they did not yet have the data they needed from the operators; and the time available would not be enough. ${ }^{60}$ The Ministry agreed to Dunham's request for funds, but by mid-1968 Ministry officials began to be very concerned that the IGS would not have anything to work on as the information they needed would really begin to flow in early $1969 .{ }^{61}$

In essence the key problem for Dunham was that North Sea operators were being deliberately sluggish in sending their data, and there was little that either the Ministry or the IGS could do about that, especially as the physical well core samples were large unwieldy items requiring careful handling and storage. However, the Ministry needed at least some 
information, and as quickly as possible. Most of the commercial operators were keen to cooperate, at least in principle and up to a point, and the North Sea Operators' Committee recommended to its members that they cooperate with any approaches for data from the IGS. ${ }^{62}$ On the one hand, they were legally obliged under the licenses to provide at least their raw data, and since the Ministry issued the licenses, they could not afford to appear uncooperative. On the other hand, some of the operators knew that the Ministry of Power, following the IGS advice, would use their data to further broader national interests rather than that of oil firms. At the time it was even suggested that a National Hydrocarbon Corporation should be established to address the problem; but the proposal was rejected. ${ }^{63}$

Dunham however now skillfully used the power and knowledge that being part of the Brundrett committee had given him. Firstly, he sought to re-orient the existing geology programs so as to bring to the fore oil security matters. His predecessor at the Overseas Geological Survey had already outlined a geological survey of the British Continental Shelf. But now Dunham used NERC and Ministry of Power's support to put forward an ambitious plan to prospect the North Sea basins and correlate geophysical and geological results with the goal of gaining greater knowledge of oil-bearing structures. ${ }^{64}$

The purpose of his plan was exactly to counter the oil firm's sluggish approach by making it possible for the IGS to collect its own data if necessary. And the IGS thus began to carry out its own surveys. Continental Shelf Unit I (CSU I) was established at the Leeds office to survey the central North Sea and the Irish Sea, along with the Mineral Assessment Unit (MAU) in London to analyze the findings. Continental Shelf Unit II (CSU II) was formed in Edinburgh to survey the northern North Sea. The MAU worked closely with the MRCC and was heavily involved in assessing North Sea resources, though it also had broader strategic concerns. In the North Sea, the first task was to establish the stratigraphy, so both 
the immediate and the long-term program for the continental shelf work were quickly established, beginning with the "interpretation of data from commercial exploration of North Sea and Irish Sea," and "offshore geophysical and geological investigations in the northern Irish Sea, Humber Estuary and North Sea off Lincolnshire." ${ }^{65}$ The IGS received about half the data the operators then held by the end of 1967, and the flow continued in 1968.

Meanwhile, Ministry officials attempted to speed the flow of data to the IGS by reassuring the operators on this score. Some therefore handed over even confidential interpretations of data to the Ministry and the IGS. ${ }^{66}$ This in fact later had the potential to cause problems between the Ministry and the operators. But they realized that the Minister might use their confidential data, or that independently collected by the IGS, to decide in favor of licenses issued to British Gas, though there was no nationalized oil interest. In this the Ministry was un-moveable, merely reiterating to the operators that its first concern was British national interests, which included British nationalized companies, though in practice it seems there was never any real conflict. Dunham has also to face the consequence of a White Paper that advocated a different allocation of funds to NERC and IGS thus putting in jeopardy both the Continental Shelf Survey and the IGS Mineral Intelligence program. ${ }^{67}$

So by the late 1960s Britain's oil security appeared under threat mainly because, in contrast with other Western European allies, Britain could not count on a nationalized oil company or insufficient investments in geophysical research. In case of conflict or due to sudden lack of supply, it was unclear if these companies would protect national or commercial interests. The threat deriving from establishing an independent national survey unit -however- convinced private oil firms operating in the North Sea to be more collaborative thus aligning to the only imperative of the British government, i.e. secure a constant supply of oil to Britain. 
By 1971 a number of major fields had been discovered by oil companies in the North Sea, and the rate of commercial exploration and discovery was rapidly increasing. A 110-mile marine pipeline was being planned from the Forties field to the coast near Peterhead, and Dunham reported that "official statements suggest that by the end of the decade a substantial proportion of the United Kingdom's oil requirements may be available from the North Sea," adding that this was "the most important geology-based development in Britain since the opening up of the coal-fields." ${ }_{68}$ The pressure began to tell on the IGS, however, in the 1970s, as basic survey work suffered while projects associated with the North Sea became paramount - not only analysis of the operators' data, but also extended seabed surveys, pipeline projects, and growing transport links. So by 1975, when Dunham left office, he had effectively put in place a comprehensive plan of explorations prioritizing British oil security by aligning oil firms to IGS plans, since -as Dunham stressed- 'the fossil fuels come first' ${ }^{69}$ Britain's concerns with oil supply had greatly reduced (notwithstanding the oil crisis of 1973).

\section{Conclusions}

In both Cold War Britain and France oil supply was at the center of national security strategies during the Cold War, due to the critical role of oil in the military-industrial complex and ever-increasing domestic demand. Guided by similar fortunes, namely discovering sources of energy in their national territories and colonies that granted a certain degree of self-sufficiency, and finding their interests in the Middle East threatened by increasing Soviet and American influence, the French and British governments attempted to secure control of oil reserves in Algeria and the North Sea respectively. While the French had relatively little difficulty in achieving quasi-exclusivity over Algerian exploration, a territory over which France had complete political control, the British strategy was made more complicated by the 
nature of the area of exploration, bordered by a number of independent European countries with their own energy and security concerns.

In the late 1940s, French oil security was shattered both by ploys to evict CFP from the Middle East and by external political factors that France and CFP could not control. To rebuild their security, the French mobilized their army of exploration geophysicists and intelligence agents to know more about what could be found in the French Union and what other countries intended to do in these regions. They moved their focus to the French Union in an attempt to guarantee national supplies from an area they could use as their own private ground. The possession and management of confidential geological information shaped the beginning of Algeria's oil era, and gave a marked advantage to French companies, which were able to use their practical monopoly rights for their exploration activities without having to worry too much about competitors. But foreign oil companies sought to establish their presence in the Sahara too, and take advantage of their influence internationally. The repeated requests of British and US oil firms to this end caused a long-lasting quarrel between French institutional sectors, resulting in the strictly government-moderated entrance of Shell into Algeria, in a joint-venture with French public agencies, or in making limited concessions to gain collaborative deals in oil exploration ventures elsewhere. The rest of Algeria, however, would be safely in French hands - at least for a few years.

The British government, in contrast with the French, could count already on a fairly constant flow of oil from the Middle East. It maintained an interest in entering other areas outside Britain, but this waned somewhat when the North Sea was revealed to a rich source available of hydrocarbons. At this point the chief strategic urgency for the British Minister of Power became to administer North Sea licenses effectively, controlling the underlying knowledge that enabled private firms to extract the oil. Yet, geostrategic knowledge both in 
the form of geological studies and an understanding of what other countries wished to do on their own territory was equally important. British security concerns stimulated both exploration and policy development within the Ministry of Power, speeding exploitation of the North Sea by encouraging both the operators and the IGS to map, survey and drill as much as possible as quickly as possible, to the extent that by the early 1970 s the possibility of British near self-sufficiency was being mooted. In essence, the British government's system of supply was based on control of licenses and thus on geophysical knowledge that would allow preventing access to other nations and a mechanism of distribution to companies permitting a regular flow of oil to the British mainland.

Oil exploration and geological knowledge had become another kind of intelligence for nations long accustomed to intelligence gathering, partially through the influence of officials such as Kinglsey Dunham and Guillaumat, who had backgrounds in the two sides of geostrategic intelligence: information on the underground resources, and the plans of those nations who had an interest in them. 
${ }^{1}$ This is, for example, the case for: Daniel Yergin, The Prize: The Epic Quest for Oil, Money, and Power. 2nd edition (New York: Simon \& Schuster, 2009); André Nouschi, La France et le pétrole : de 1924 à nos jours (Paris: Picard, 2001); Jean Prouvost (ed.) La recherche pétrolière française (Paris: Éditions du CTHS, 1994).

${ }^{2}$ Robert Jervis, “Cooperation Under the Security Dilemma”, World Politics, 30:2 (1978): 167-214; R. Jervis, “Was the Cold War a Security Dilemma?” Journal of Cold War Studies, 3 (2001): 36-60. ${ }^{3}$ Amongst other: the archives of the French oil firm TOTAL (Archives Historiques du Groupe TOTAL, AH TOTAL); the US National Archives and Records Administration (NARA); and the British National Archive (TNA).

${ }^{4}$ James H. Bamberg, The History of the British Petroleum Company, volume 2: the Anglo-Iranian Years, 1928-1954 (Cambridge: Cambridge University Press, 1994).

${ }^{5}$ On the post-war reconstruction of France from a political and diplomatic point of view, see: Irwin M. Wall, The United States and the Making of Postwar France, 1945-1954 (Cambridge: Cambridge University Press, 1991); William I. Hitchcock, France Restored: Cold War diplomacy and the quest for leadership in Europe, 1944-1954 (Chapel Hill/London: University of North Carolina Press, 1998); Jean-Pierre Rioux, The Fourth Republic, 1944-1958 (Cambridge: Cambridge University Press, 1987).

${ }^{6}$ CFP, Minutes of the Meeting of the Board of Directors (MBD, henceforth), 5 June 1946, pp. 2-3, TOTAL-CFP, b. 92.10/1, AH TOTAL.

${ }^{7}$ CFP - Minutes of MBD - 6 November 1946, p. 3, TOTAL-CFP, b. 92.10/1, AH TOTAL.

${ }^{8}$ CFP - Minutes of MBD - 27 December 1946, pp. 2-4, TOTAL-CFP, b. 92.10/1, AH TOTAL. ${ }^{9}$ Irvine H. Anderson, ARAMCO. The United States and Saudi Arabia. A Study of the Dynamics of Foreign Oil Policy, 1933-1950 (Princeton: Princeton University Press, 1981). pp. 153-154. Also in: Nouschi, La France et le pétrole, 198. See also: A. Nouschi, "Un tournant de la politique pétrolière française: les Heads of Agreement de novembre 1948", Relations Internationales 44 (1985): 379389; Burton I. Kaufman, The Oil Cartel Case: A Documentary Study of Antitrust Activity in the 
Cold War Era (Westport: Greenwood Press, 1978), 123-36.

${ }^{10}$ Jean Rondot, La Compagnie Française des Pétroles. Du franc-or au pétrole-franc (Paris: Plon, 1962), 93-95; Michael B. Stoff, Oil, War, and American Security. The Search for a National Policy on Foreign Oil, 1941-1947 (New Haven and London: Yale University Press, 1980), 200.

${ }^{11}$ Pierre Fontaine, La morte étrange de Conrad Kilian, inventeur du pétrole saharien (Paris: Les Sept Couleurs, 1959), Chaps. 6-7.

${ }^{12}$ Ibid., 23.

${ }^{13}$ Ibid., 65-6.

${ }^{14}$ Alain Perrodon, "Historique des recherches pétrolières en Algérie”, in J. Prouvost (ed.), La recherche pétrolière française, 323-340, on 325.

${ }^{15}$ Ibid., 326.

${ }^{16}$ Fontaine, La morte étrange de Conrad Kilian, 64-69.

${ }^{17}$ CFP, Minutes of MBD, 27 December 1946, p. 2-4 in TOTAL-CFP, b. 92.10/1, AH TOTAL.

${ }^{18}$ Henri Bonnet to the US Under-Secretary of State for Economic Affairs William L. Clayton, 4 January 1947, Foreign Relations of the United States (1947), V, 627-9, NARA.

${ }^{19}$ Emmanuel Catta, Victor De Metz. De la CFP au Groupe TOTAL (Paris: Total Edition Presse, 1990). See also Rondot, La Compagnie Française des Pétroles, 97.

${ }^{20}$ CFP, Minutes of MBD, 5 March 1947, pp. 3-5 in TOTAL-CFP, b. 92.10/1, AH TOTAL. See also: Anderson, ARAMCO, 158.

${ }^{21}$ CFP, Minutes of MBD, 4 June 1947, pp. 3-5 in TOTAL-CFP, b. 92.10/1, AH TOTAL. See also: Nouschi, La France et le pétrole, 200.

${ }^{22}$ Pierre Péan, in George-Henri Soutou and Alain Beltran (eds.), Pierre Gullaumat, la passion des grands projets industriels (Paris: Institut d'Histoire de l'Industrie et Editions Rive Droite, 1995), 12-13; P. Péan and Jean-Pierre Séréni, Les émirs de la République (Paris: Seuil, 1982), 28.

${ }^{23}$ C. Layat, A. Clement, G. Pommier, and A. Buffet, "Some technical aspects of refraction seismic prospecting in the Sahara”, Geophysics 26:4 (1961): 437-46. See also: A. Beltran and Sophie 
Chauveau, Elf Aquitaine, des origines a 1989 (Paris: Fayard, 1998), 59.

${ }^{24}$ Perrodon, "Historique des recherches pétrolières en Algérie", 328.

25 Unlike, for example, French colonies in sub-Saharan Africa, the three départements of Algeria were considered integral parts of the French political unit.

${ }^{26}$ Minutes of the Conference held on 19 June 1947 at the Under-Directorate of Algeria, p. 4 in ELFERAP, b. 07AH0168-6, Papers SN REPAL, AH TOTAL.

${ }^{27}$ On the Monnet Plan see Gérard Bossuat, La France, l'aide américaine et la construction européenne, 1944-1954 (Paris: Comité pour l'histoire économique et financière de la France, 1997). 28 The Algerian Government General, established in July 1834, was responsible for the administration of French North African territories.

${ }^{29}$ Minutes of the Conference held on 19 June 1947 at the Under-Directorate of Algeria, p. 4 in ELFERAP, b.07AH0168-6, Papers SN REPAL, AH TOTAL [my own translation].

${ }^{30}$ Ibid., 8 [my translation].

${ }^{31}$ SN REPAL, Minutes of the 4th MBD, 24 June 1947, ELF-ERAP, b. 07AH0168-28, Papers SN REPAL, AH TOTAL.

${ }^{32}$ SN REPAL, Minutes of the 6th MBD, 30 December 1947, in ELF-ERAP, b. 07AH0168-28, papers of SN REPAL, AH TOTAL.

${ }^{33}$ Giovanni Buccianti, Enrico Mattei: Assalto al potere petrolifero mondiale (Milan: Giuffrè, 2005), $151-2$

${ }^{34}$ Gulf’s Legal Department [unsigned] to Yves Chataigneau [via French Embassy in Washington], 10 September 1947, in ELF-ERAP, b. 07AH0168-6, Papers SN REPAL, AH TOTAL.

${ }^{35}$ On Paul Moch see Péan and Séréni, Les émirs de la République.

${ }^{36}$ P. Guillaumat to Inspector General of Mines in Alger Georges Betier, 9 April 1948 in b.07AH0168-28, ELF-ERAP; and SN REPAL, Minutes of the 7th MBD, 14 January 1948 in b.07AH0168-6, SN REPAL, AH TOTAL. 
${ }^{37}$ Paul Moch to Directeur des carburants P. Guillaumat, 18 October 1950 and Note by Governor General of Algeria Marcel-Edmond Naegelen, "Recherches d'hydrocarbures dans le Sahara”, ELFERAP, b. 07AH0168-6, Papers SN REPAL, AH TOTAL.

${ }^{38}$ BRP, Minutes of the 29th MBD, 30 October 1951, pp. 6-9 in b. 10AH0832-26, ELF-ERAP and SN REPAL, Minutes of the 29th MBD, 24 November 1951, pp. 16-17, in b.07AH0168-6, AH TOTAL.

${ }^{39}$ R. Goetze to BRP Delegate General Paul Moch, 27 February 1952 in ELF-ERAP, b.07AH0168-6, SN REPAL, AH TOTAL.

${ }^{40}$ R. Goetze to BRP Delegate General Paul Moch, 17 September 1952 in ELF-ERAP, b.07AH01686, SN REPAL, AH TOTAL.

${ }^{41}$ A. Morange, A. Perrodon, and F. Héritier, Les grandes heures de l'exploration pétrolière du groupe ELF Aquitaine (Boussens: Elf Aquitaine Éditions, 1992), 97. See also Perrodon, "Historique des recherches pétrolières en Algérie", 327.

${ }^{42}$ See Bamberg, The History of the British Petroleum Company.

${ }^{43}$ Ministry of Power report, 22 February 1966, in "Security of oil supplies; and UK stockpiling policy", POWE 63/75, TNA.

${ }^{44}$ Ibidem.

${ }^{45}$ P. E. Kent, "North Sea Exploration - A Case History", The Geographical Journal 133:3 (1967), 289-301, on 290. See also P. E. Kent, “The North Sea - Evolution of a Major Oil and Gas Play”, Facts and Principles of World Petroleum Occurrence 6 (1980), 633-652.

${ }^{46}$ Kent, "North Sea Exploration - A Case History", 291-29.

${ }^{47}$ Øystein Noreng, Oil Industry and Government Strategy (Boulder, CO: ICEED, 1980), 40; see also Helge Ryggvik, The Norwegian Oil Experience: A toolbox for managing resources? (Oslo: University of Oslo, 2010), 11.

${ }^{48}$ Ministry of Power, Fuel Policy. Presented to Parliament by the Minister of Power by Command of Her Majesty, November 1967 (London: H.M. Stationary Office, 1967), 5. 
49 "North Sea Oil", General Correspondence, Economic Relations (U): Supplies, FO 371/178156, TNA.

50 "North Sea Oil and Gas", General Correspondence, International Oil (IOD), FO 371/187603, TNA.

${ }^{51}$ Hubert Scholes to John T. Fearnley, 18 April 1966, in "North Sea Oil and Gas”, FO 371/187603, TNA.

${ }^{52}$ Untitled Memorandum, 21 June 1967, in "Investigation by the IGS of the geophysics of the North Sea from information given by offshore licencees", POWE 63/201, TNA.

${ }^{53}$ Ibidem. For an overview on the institution's history see: Harold E. Wilson, Down to earth: one hundred and fifty years of the British Geological Survey (Edinburgh: Scottish Academic Press, 1985). Post-1967 developments are examined in Dennis Hackett, “Our corporate history: key events affecting the British Geological Survey, 1967-1998," British Geological Survey Technical Report WQ/99/1 (available at: www.bgs.ac.uk, accessed 19/8/2013).

${ }^{54}$ G. A. L. Johnson, “Sir Kingsley Charles Dunham, 1910-2001” Biographical Memoirs of Fellows of the Royal Society 49 (2003): 147-162, on 155.

${ }^{55}$ Richard Aldrich, Espionage, Security, and Intelligence in Britain, 1945-1970 (Manchester: Manchester University Press, 1998), 60.

${ }^{56}$ On this committee see Jon Agar and Brian Balmer, "British Scientists and the Cold War: the Defence Research Policy Committee and Information Networks, 1947-1963”, Historical Studies in the Physical Sciences 28:2 (1998): 209-252.

${ }^{57}$ K. Dunham, “IGS Final Report, 1967-1975,” Appendix 1 in Hackett, “Our corporate history: key events affecting the British Geological Survey, 1967-1998," 9-11.

58 Ibidem, 10.

${ }^{59} 1^{\text {st }}$ Meeting of the Mineral Resources Consultative Committee, in MRCC Agenda, Minutes and Papers, ED 222/1, TNA; “Investigation by the IGS of the geophysics of the North Sea”, POWE 63/201, TNA POWE 63/201, TNA. 
60 "Investigation by the IGS of the geophysics of the North Sea", POWE 63/201, TNA.

${ }_{61}$ "IGS: Continental Shelf Programme", POWE 63/465, TNA.

${ }^{62}$ Ian McCartney to N. E. Martin, 11 January 1968, in "Investigation by the IGS of the geophysics of the North Sea", POWE 63/201, TNA.

${ }^{63}$ Dunham to R. J. H. Beverton (received 21 Dec 1967), "Investigation by the IGS of the geophysics of the North Sea”, POWE 63/201, TNA.

${ }^{64}$ K. Dunham, “IGS Final Report, 1967-1975,” 9.

${ }^{65}$ IGS, Annual Report 1967 (London: HMSO, 1968), 63.

${ }^{66}$ Ian McCartney to N. E. Martin, 11 January 1968, in "Investigation by the IGS of the geophysics of the North Sea", POWE 63/201, TNA.

${ }^{67}$ K. Dunham, “IGS Final Report, 1967-1975,” 10.

${ }^{68}$ IGS Annual Report 1971 (London: HMSO, 1972), 2.

${ }^{69}$ K. Dunham, "IGS Final Report, 1967-1975," 11. 